\title{
A NOVA LEI FEDERAL DE CONCESSÕES E PERMISSÕES DE SERVIÇOS PÚBLICOS E OBRAS PÚBLICAS
}

\author{
Edmir Netto de Araújo \\ Professor Associado de Direito Administrativo da \\ Faculdade de Direito da Universidade de São Paulo \\ Procurador do Estado e da Assessoria Jurídica do Governo
}

Resumo:

Porque se trata de licitações e contratos administrativos ao focalizar o tema das concessões e permissões de serviços públicos? É que a Constituição, diferentemente das anteriores, dispôs em seu art. 175 que incumbe ao Poder Público ou sob regime de concessão ou permissão, mas sempre através de licitação de tais serviços, sendo que na forma da Lei (de competência da União, para legislar sobre normas gerais sobre licitações e contratos administrativos), serão disciplinados os regimes das concessionárias e permissionárias de serviço público (não se fala em concessão ou permissão de uso de bens públicos) o caráter especial de seu contrato, etc., os direitos dos usuários, a política tarifária e a obrigação de manter serviço adequado.

O Estado de São Paulo já havia disciplinado, pela Lei n. $7.835 / 92$, o assunto, inclusive sobre as licitações e até mesmo sua dispensa, licitação essa que será a concorrência e determinando (art. $3^{\circ}, \S$ único, que o Poder concedente por ato ou por delegação, publica a definição do objeto, área de atuação, prazo e diretrizes a serem observadas no Edital de concorrência (o que foi repetido no art. $5^{\circ}$ da Lei federal n. 8.987/95) e, por isso, na recente decisão de concessão do sistema rodoviário Anhangüera/Bandeirantes, foram publicados o Decreto n. 40.077 , de 10 de maio de 1995, e a Resolução n. 16, do secretário de Transportes, de 11 de maio de 1995 .

Sobre a licitação bastam por comentários, sem antes dizer, a confrontação da lei estadual com a federal, prevalecendo o que em contrário dispuser esta última. Por exemplo, a lei federal não prevê casos de dispensa de licitação, matéria que com certeza constitui norma geral, da competência da União (art. 22, inciso XXVII, da Constituição Federal).

Mas as questões que suscitam divergências de interpretação se referem mais diretamente aos contratos de concessão e, depois da lei federal, também de permissão de serviço público. Minha função aqui não é ensinar o que é contrato administrativo a uma categoria, de meus colegas, que mais entende do assunto, mas provocar o debate, para que se conclua sobre as imperfeições e a necessidade ou não de modificações que viabilizem a aplicação da lei. 
Abstract:

Why refer to licitations and administrative contracts when focus the theme of concessions and permissions of public services?

The fact is that the 1988 Constitution, differently from the previous ones, has stated, in article 175 that is a task of Public, directly or under the rule of concession or permission, but always through licitation, the operation of such services, being in form of the law (it's private competence of the Union to legislate about general rules on licitation and administrative contracts) will the rules of concessionaires and permissionaires of public services be disciplined (we're not mentioning either concessions or permissions to use public properties), the feature of contract, etc., including the user's rights, the fare politics and the obligation to keep appropriate service.

São Paulo State had already disciplined the issue through Law $7.835 / 92$, including rules about licitation and even its exceptions, stating that this licitation must be the concurrency, and determining (article 3, sole $\S$, that the Public Power, act of his own, or by delegation, would publish the definition of object, area of operation, time terms and directions to be observed in the concurrency "Edital" (this was repeated by the federal Law $8.987 / 95$, article 5th). That's why in the recent governmental decision of concession of the Anhaguera/Bandeirantes system, were published the Decree 40.077, 10.05.95, and the Transport Secretary Resolution n. 16, in the following day.

Such comments about licitation are enough, by now, but it's worth stating that by confronting the State law the Federal law, was prevailed what in opposite has been stated on the latter.

For example, the Federal law does not foresee cases of licitation exceptions, issue that certainly constitutes "general" rule, of Union competence (art. 22, XXVII, Federal Constitution).

But the questions that might be misunderstood, refer more specifically to the contracts of concession, and, after that Federal law, the permission contracts as well. My desire, here, is not to teach what is an administrative contract, but provide that a debate could arise, in order to get to a conclusion on the imperfections and the necessity or not of changes on Federal law, or interpretations that could make the application of the law possible.

Introdução

1. A União, Governo Federal, vem disciplinar, em nível nacional, o regime de concessão e permissão da prestação de serviços públicos previsto no art. 175 da Constituição Federal, por intermédio da Lei Federal n. 8.987, de 13 de fevereirú de 1995, catalogando-a como instrumento indispensável para a parceria entre o Poder Público e a iniciativa privada, na melhoria de tais atividades, que 
ocasionaria, pelo menos, economia de recursos públicos em certas áreas de serviços que sob tal regime possam ser delegados a particulares. Logo em seguida, foi editada Medida Provisória, que, embora predominantemente destinada a disciplinar a concessão dos serviços de energia elétrica, indicou de forma exaustiva, em numerus clausus, quais os serviços públicos que seriam objeto desse regime: geração, transmissão e distribuição de energia elétrica; transportes coletivos das várias espécies; telecomunicações (nos termos do art. 21, XI, da CF); exploração, precedida ou não de obra, de portos, infra-estrutura aeroportuária, aeroespacial, obras viárias, barragens, contenções, eclusas, diques; distribuição local de gás canalizado (observado o art. $25, \S 2^{\circ}$, da CF); saneamento básico; tratamento e abastecimento de água; limpeza urbana; tratamento de lixo e serviços funerários, conforme $o$ art. $1^{\circ}$, seus incisos, parágrafos e alíneas dessa medida, que, no $\S 1^{\circ}$ exige lei autorizativa para concessão ou permissão de outros serviços não-constantes de tal relação. $\mathrm{O}$ assunto merece exame nos vários níveis federativos, especialmente no Estado de São Paulo, que já possui, a respeito, a Lei n. 7.835 , de 8 de maio de 1992, porque em se tratando de licitação e contrato administrativo, a Constituição Federal, em seu art. 22, inciso XXVII, atribui à União a competência privativa para legislar sobre normas gerais nessa matéria, aplicáveis à Administração direta e indireta, inclusive fundações, nas esferas federal, estadual, municipal e do Distrito Federal. Aliás, o parágrafo único do art. $1^{\circ}$ da citada Lei federal n. 8.987/95 determina expressamente que essas unidades da Federação que já tenham legislado sobre a matéria, adaptem prontamente sua legislação às disposições ora promulgadas.

Contratos Administrativos

2. Não se pode falar sobre concessão de serviço público sem focalizar, como pré-requisito, a noção de contrato administrativo.

Contrato é uma categoria jurídica, espécie de negócio jurídico.

Negócio jurídico é a convergência, em acordo ou consenso, de duas ou mais declarações de vontade que se orientam no sentido da produção dos efeitos jurídicos "com elas desejados, criando uma relação juridica nova, inexistente antes das declarações, na forma que o ordenamento jurídico prescreve" ou então, "admite ou atribui conseqüencias às mesmas declarações" (nosso Do negócio juridico administrativo, Ed. Revista dos Tribunais, p. 167, 1992). 
Caso esse acordo seja de vontades opostas (e não paralelas, como nos convênios ou consórcios), criando obrigações recíprocas (e, portanto, sinalagmáticas), cujas prestações sejam intrinsecamente equivalentes (e, portanto, comutativas), sendo tal acordo obviamente consensual e realizado intuitu personae, estaremos diante do negócio jurídico denominado contrato. E, na hipótese de que tal contrato envolva objeto e finalidade públicos, celebrado pela Administração por seu agente competente, após o devido procedimento legal e contenha explícita ou implicitamente cláusulas exorbitantes do direito comum (que preferimos chamar cláusulas de prerrogativa), que o submetam a regime jurídico de Direito Administrativo, firmando a supremacia da Administração na relação jurídica, quando prevalece o interesse público, sob certas condições, sobre o particular, esse será um contrato administrativo (nosso Contrato Administrativo, Ed. Revista dos Tribunais, p. 51, 1987). Lúcia Valle Figueiredo (Curso de Direito Administrativo, Malheiros Editores, pp. 329-31, 1994) fala, com muita propriedade, em "desnivelamento das partes" jus variandi, e "instabilização do vínculo contratual" para caracterizar essa situação de verticalidade na relação negocial da Administração, entretanto, não se exerce de forma indiscriminada, pois todo o direito positivo, mais doutrina e jurisprudência, se inclinam no sentido da manutenção do equilíbrio econômico-financeiro original do contrato, gerando ao contratado o direito à recomposição desse equilíbrio sempre que a Administração alterar $o$ contrato de forma a afetar essa equação financeira. Caso assim José Cretella Jr. (Comentários à Constituição de 1988, Ed. Forense Universitária, $8^{\circ}$ v., 1993, p. 4.108), acrescenta, tendo em vista esse desnivelamento, que o contrato administrativo (qualquer deles) é oneroso, sinalagmático perfeito, comutativo, realizado intuitu personae, e, como o entende praticamente a unanimidade da doutrina, "do tipo dos contratos de adesão."

Já quando a Administração se coloca, por opção ou disciplina legal específica, no mesmo patamar que o particular contratante (como nas locações, doações, comodatos, contratos trabalhistas, etc.) o respectivo contrato será um contrato "da Administração", mas não contrato "Administrativo" 
Supremacia da Administração no Contrato

3. Essa supremacia não fosse, restaria anulado o requisito da comutatividade, e, no mais das vezes, também o da reciprocidade dos contratos administrativos.

Assim é que a própria Lei n. 8.666/93, ao prever a possibilidade da rescisão unilateral do contrato por "razões de interesse público" (v.g. art. 78, inciso XII), imediatamente garante (art. 79, $\S 2^{\circ}$ ) o ressarcimento dos prejuízos regularmente comprovados, do contratado. É o mesmo que faz, depois de prever a mutabilidade unilateral do contrato, no art. 65, incisos I e II, "d" para "restabelecer a relação que as partes pactuaram inicialmente", e "objetivando a manutenção do equilíbrio econômico-financeiro inicial do contrato."

Desfazimento de Atos Administrativos e Contratos

4. Também, ao menos em princípio, não se "revogam" contratos, que são atos bilaterais: anulam-se (quando ocorrem nulidades insanáveis na licitação ou na própria contratação), de forma retroativa, como está no art. 59 da Lei n. 8.666/93; ou rescindem-se (por motivo de interesse público, infração contratual ou amigavelmente, por mútuo dissenso), unilateral, amigável ou judicialmente, como prescrevem o art. 79, seus incisos e parágrafos, do mesmo diploma legal. As permissões, outorgadas a título precário por ato unilateral, podem ser revogadas, mas não contratos bilaterais.

Revogação é ato administrativo unilateral desconstitutivo, manifestação privativa da Administração, que objetiva suprimir total ou parcialmente os efeitos de ato legítimo, por razões de oportunidade ou conveniência (jamais razões de legitimidade ou legalidade), como há muito ensinavam Arnaldo De Valles ("La validitá degli atti amministrativi" Ed. Athenaeum, Roma, p. 387, 1917) e Gaston Jèze ("Principes généraux de droit administratif" Lib. Giard \& Brière, Paris, v. II, pp. 176 e ss., 1926), sendo claro que seus efeitos se verificam $a$ partir de sua edição, ex nunc, respeitando-se os efeitos anteriores (Súmula STF n. 473), mas extinguindo o ato.

No Direito brasileiro, assim pensam José Cretella Jr. (Curso de Direito Administrativo, Ed. Forense, 1989, p. 305), Maria Sylvia Zanella Di Pietro (Direito 
Administrativo, Ed. Atlas, pp. 205-6, 1994), Hely Lopes Meirelles (Direito Administrativo Brasileiro, Malheiros Editores, p. 184, 1993), Lúcia Valle Figueiredo (Curso de Direito Administrativo, Malheiros Editores, p. 138-9, 1994), e Celso Antonio Bandeira de Mello (Curso de Direito Administrativo, Malheiros Editores, p. 217, 1993). Desses autores, Maria Sylvia Zanella Di Pietro e Lúcia Valle Figueiredo acrescentam, ainda, serem irrevogáveis os atos vinculados e não se conhece vinculação maior (à lei, à licitação e ao respectivo Edital) que o ato bilateral contratual.

Cláusulas Exorbitantes nos Contratos Administrativos

5. As cláusulas contratuais ditas "exorbitantes" do direito comum, ou de "prerrogativa", cuja presença em um contrato lhe dá "la marque du droit public" (André De Laubadère, Traité theorique et pratique des contrats administratifs, v. I, Librairie Général de Droit et Jurisprudence, Paris, p. 85, 1956), caracterizando-o como contrato administrativo, em relação de preponderância sobre o contratado, são válidas e aplicáveis mesmo que constem apenas implicitamente no corpo clausular do instrumento da avença, pois (especialmente nas concessões de serviço público) decorrem da própria titularidade do serviço.

São as seguintes as cláusulas "exorbitantes" mais apontadas pela doutrina: mutabilidade unilateral do contrato (sob certas condições legais, observado o equilibrio econômico-financeiro); rescisão unilateral do contrato (por infração contratual, "pleno direito" ou "razões de interesse público" em matéria de concessões de serviço público, fala-se em "caducidade", "resgate" ou "encampação"), sem a participação do Poder Judiciário, assegurando-se ampla defesa no caso de infração; promoção expropriatória (a declaração de utilidade ou necessidade pública é privativa dos respectivos Chefes de Executivo, no Brasil); percep̧̧ão de tributos (não sua decretação); ocupação do domínio público; substituição de elementos do concessionário, em razão da qualidade dos serviços; aplicação unilateral de penalidades (também sem a participação do Judiciário, mas observada a garantia de ampla defesa); imposição de meios de execução dos serviços; privilégios fiscais; possibilidade de exclusividade e de amparo ao concessionário; retenção sobre a obra ou serviço; inadmissibilidade da "exceptio non adimplenti contractus" contra o Estado (a lei vem mitigando a rigidez desse 
princípio, admitindo-a em certos casos) e outras hipóteses (cf. nosso Contrato Administrativo, citado, pp. 126-53).

Essas prerrogativas não constituem simplesmente "faculdades" da Administração, mas na verdade cada uma delas é "poder-dever", que deve ser exercido, sob pena de responsabilidade, quando se apresente a oportunidade e o interesse público assim o exija, como, por exemplo, na modernização dos serviços concedidos. É oportuno mencionar o comentário que, a respeito, faz Hely Lopes Meirelles (Direito Administrativo Brasileiro, citado, p.198): "o poder de alteração e rescisão unilateral do contrato administrativo é inerente à Administração, pelo que podem ser feitas ainda que não previstas expressamente em lei ou consignadas em cláusula contratual", concluindo que tal poder "constitui preceito de ordem pública, não podendo a Administração renunciar previamente à faculdade de exercê-lo."

\section{Concessão de Serviço Público}

6. Vejamos agora o que se pode entender por "concessão" e "concessão de serviço público"

"Conceder (Novo Dicionário Aurélio, Editora Nova Fronteira, 1993). 1. Permitir, facultar. 2. Dar, entregar. 3. Admitir por hipótese. 4. Concordar, convir, anuir."

Em qualquer caso, verifica-se que é a aquiescência de alguém que detém poder ou direito sobre algo (titularidade), para a ação de outrém. Assim, o Poder Público, titular do patrimônio e dos serviços públicos, concede ou permite (ou até simplesmente autoriza) o uso privativo de bem público por particular, ou o desempenho de serviços públicos delegáveis (pois há serviços públicos indelegáveis), a particulares ou outras entidades públicas.

Até a Constituição de 1988 não era incomum que mesmo as concessões, mas principalmente as permissões e autorizações fossem outorgadas por ato administrativo (ou legislativo) unilateral do Poder Público, sem qualquer contrato (decreto de concessão de lavra de mineração; lei que cria empresa estatal concessionária de serviços públicos, etc.), mas no caso de concessão de serviços públicos a particulares, tem-se assentado na doutrina e na jurisprudência que c regime adequado é o contratual e a Constituição Federal vigente, em seu art. 175, inciso I, assim o consagra. Tal não ocorria, no entanto, no âmbito das permissões e 
autorizações na esfera doutrinária, tradicionalmente outorgadas (e não-contratadas) a título unilateral e precário, sem prazo determinado, e canceláveis (ou revogáveis, porque atos unilaterais da Administração) a qualquer tempo, ao alvedrio do Poder Público, sem indenização. Mas, pelo citado inciso I do art. 175 da CF, pode-se inferir que mesmo as permissões de serviço público (não se mencionam as de uso) se agregam ao regime contratual obrigatório.

Concessão de serviço público è "a transferência, temporária ou resolúvel, por uma pessoa coletiva de direito público, de poderes que lhe competem para outra pessoa singular ou coletiva pública ou privada, a fim de que esta execute serviços por sua conta e risco, mas no interesse geral." (José Cretella Jr., Tratado de Direito Administrativo, v. III, Ed. Forense, p. 121, 1967).

Realmente, pelo contrato de concessão, "a Administração delega a execução remunerada de serviço ou de obra pública ou de utilidade pública, ou cede o uso de um bem público ao particular contratante para que o explore ou utilize pelo prazo e nas condiçóes regulamentares e contratuais." (Hely Lopes Meirelles, Direito Administrativo Brasileiro, Malheiros Editores, pp. 240-1, 1993).

Como se vê, pela doutrina mais significativa, "entende-se por concessão de serviço público o ato complexo através do qual o Estado atribui a alguém o exercício de um serviço público e este aceita prestá-lo em nome do Poder Público sob condições fixadas e alteráveis unilateralmente pelo Estado, mas por sua conta, riscos e perigos, remunerando-se pela cobrança de tarifas diretamente dos usuários do serviço e tendo a garantia de um equilibrio econômico-financeiro" (Celso Antonio Bandeira de Mello, Curso de Direito Administrativo, Malheiros Editores, p. 327, 1993).

Já para Maria Sylvia Zanella Di Pietro (Direito Administrativo, Ed. Atlas, p. 218, 1993), "concessão de serviço público é o contrato administrativo pelo qual a Administração delega a outrém a execução de um serviço público, para que $o$ execute em seu próprio nome, por sua conta e risco, assegurando-lhe a remuneração mediante tarifa paga pelo usuário."

Também não discrepamos dessas conceituações, ao entender que "concessão de serviço público é a transferência por contrato, temporária ou resolúvel, de execução de serviços públicos essenciais, secundários ou de simples interesse público ou utilidade pública, dos quais a Administração tem a titularidade, para que, por sua conta e risco, no interesse geral, o concessionário os 
desempenhe ou explore." (nosso Do negócio jurídico administrativo, Ed. Rev. Trib., p. 133, 1992)

Melhor esclarecendo (nosso Contrato Administrativo, cit., p. 87), as características da concessão, na prática, podem resumir-se à existência de uma relação administrativa entre a Administração concedente e o concessionário, para a incumbência especifica da gestão de um serviço público, feita por prazo determinado, sendo que tal serviço é exercido pelo concessionário em seu próprio nome, cabendo-lhe portanto os riscos; e sabendo-se que a Administração delega ao concessionário não poderes públicos mas o exercício de determinados poderes; e que o concessionário, ao invés de receber do Estado, em princípio, recebe tarifas do usuário do serviço público concedido. O concessionário pode ser (e geralmente o é) particular, mas nada impede que seja entidade pública ou empresa sob seu controle acionário.

Natureza Jurídica das Concessões

7. Já quanto à natureza jurídica da concessão, embora a doutrina estrangeira e mesmo a brasileira a tenham focalizado de diversas formas, como sendo "ato unilateral" (Fritz Fleiner, Les principes généraux du droit administratif allemand, trad. C. Eisenmann, Librairie Dellagrave, Paris, p. 213, 1993); "dois atos unilaterais" (Oreste Ranelletti, Teoria generale della autorizzazioni e concessioni amministrativa, Jurisprudenza Italiana, v. IV. p. 15, 1894) "contrato de direito privado" (Cesare Cammeo, I contrati della pubblica amministrazione, Casa Editrice Poligráfica Universitária Dott. Carlo Cya, Firenze, p. 40, 1937); Ruy Barbosa, Os privilégios exclusivos na jurisprudência constitucional dos Estados Unidos, Empresa Fotomecânica do Brasil, p. 18, 1911; Augusto Olímpio Viveiros de Castro, Tratado de Ciência da Administração e Direito Administrativo, Ed. Jacinto R. dos Santos, Rio, p. 263, 1814); ou "contrato de direito misto" (José Gascon y Marin, Tratado de derecho administrativo, EISA, Madrid, p. 368, 1950), a verdade é que, atualmente não há mais dúvida de que se trata de contrato de direito público, ou mais exatamente, como ensina José Cretella Jr. (Tratado de Direito Administrativo, v. III, Ed. Forense, 1967) "contrato de direito público, oneroso, sinalagmático, comutativo e realizado intuitu personae" assim como também entende Hely Lopes Meirelles (Direito Administrativo Brasileiro, Malheiros Editores, p. 241, 1993), para quem "a concessão pode ser de serviço, de obra ou de uso de bem público, todas 
elas consubstanciadas em contrato administrativo, bilateral, comutativo, remunerado e realizado intuitu personae"

Concessão de Obra Pública

8. Já há algum tempo, alguns autores (como Hely Lopes Meirelles, Direito..., cit., p. 241-2, ou José Cretella Jr., Tratado..., cit., v. III, p. 92) vinham distinguindo a chamada "concessão de obra pública", muito comum nos Estados Unidos da América do Norte, pela qual o particular constrói ou implanta certo equipamento de uso público (estradas, pontes, viadutos, etc.), e em troca recebe o direito de explorar economicamente esse equipamento (serviço público ou de utilidade pública) por determinado prazo, findo o qual as benfeitorias se incorporam ao patrimônio do Poder Público concedente. Entendemos (nosso Contrato..., cit., p. 86) que, no caso, se trata, na verdade, de espécie de concessão de serviço público, que contém a condição de realizar obras para construir ou implantar o bem e/ou serviço a ser explorado, como poderia conter outro tipo de condição, se o equipamento já foi construído pelo Estado. Mas a Lei n. 8.987/95 agasalhou a modalidade, em seu art. $2^{\circ}$, inciso III, conceituando-a da forma citada, como investimento remunerado e amortizado pelo resultado da exploração do respectivo serviço.

\section{Extinção das Concessões}

9. Merecem especial destaque formas de extinção (nosso Contrato Administrativo cit., pp. 96-100) das concessões, considerando-se que o Poder Público jamais perde a titularidade do serviço público concedido, e, portanto, não devem as concessões prolongar-se indefinidamente, desvirtuando a finalidade do instituto.

a. Quanto à pessoa do concessionário, extingue-se a concessão por sua morte; ou extinção, ou falência da empresa. Sendo a concessão intuitu personae, não se transfere por sucessão; no caso de falência, a extinção (art. 201, § $3^{\circ}$ Decreto-Lei n. 7.661/45) é ipso jure.

b. A extinção natural é o término do prazo da concessão, com a reversão dos bens e serviços ao concedente. 
c. A retomada unilateral dos serviços e bens concedidos, por motivo que, a exclusivo critério do concedente, seja de interesse público, tem o nome de resgate, ou encampação do serviço. É a avocação do serviço, sem culpa ou infringência contratual do concessionário, por motivo de interesse público, e mediante justa indenização: o concessionário não pode opor-se à encampação, podendo o Poder Público entrar imediatamente na posse dos bens e serviços, limitando-se o direito do concessionário à eventual indenização. Em outros contratos administrativos, é a rescisão "por razões de interesse público", unilateral.

d. A concessão outorgada por ato unilateral administrativo ou legislativo pode ser revogada pela mesma via, quando cessam os motivos em virtude dos quais foi efetivada, geralmente em razão de progressos técnicos que tornam o serviço obsoleto nos termos originais. Difere da encampação, pois nesta a Administração assume, ao menos temporariamente, o serviço encampado; e da anulação, que supõe invalidação do contrato $a b$ initio, por ilegalidade.

e. Pressupondo-se a existência de um contrato administrativo de concessão de serviço público válido e em vigência, a relação pode ser desfeita antes de seu término através da rescisão.

$\mathrm{Na}$ rescisão "amigável" por acordo entre as partes (mutuus dissensus), estas desfazem o que, no caminho inverso, se convencionou, mediante encontro de contas, observado o princípio da legalidade.

Mas o Poder concedente tem não-só o direito, mas também o poder dever de rescindir brusca e unilateralmente, sem a participação, em princípio, do Poder Judiciário, o contrato (qualquer contrato, inclusive o de concessão) administrativo quando ocorre infração contratual punível com tal penalidade. Aliás, é uma das cláusulas denominadas exorbitantes, como se viu há pouco, operante mesmo que não conste de lei ou do contrato, decorrente do próprio regime contratual administrativo. No caso da concessão de serviço público, a rescisão unilateral por infração contratual, sem direito a indenização ao concessionário, chama-se caducidade, e, repetimos, é poder-dever do administrador público competente, sob pena de responsabilidade.

A rescisão judicial geralmente ocorre quando é a Administração a inadimplente contratual, caso em que, de acordo com o que a lei prescreve, o concessionário pode pleitear a rescisão do contrato, mas não tem o poder de fazê-lo unilateralmente, como a Administração. Ocasionalmente, essa modalidade de rescisão pode ser promovida pelo concedente, quando de interesse público para 
eventual exoneração de compromissos e reparações ou indenizações. Mas não é o que a nova lei descreve, como se verá adiante.

f. Os autores falam ainda em "renúncia", "nacionalização" dos serviços, "força maior", factum principis, noções que, não obstante, se acomodam conceitualmente às hipóteses até agora descritas.

José Cretella Jr. (Tratado de Direito Administrativo, cit., p. 161-82) aponta, como causas de extinção das concessões, a terminação do prazo, o resgate (ou encampação), a revogação, a caducidade (como espécie de rescisão ou resilição), a força maior, a morte do concessionário, a falência, a renúncia e a nacionalização. Revogação, para o autor, que considera "ato administrativo" como manifestação unilateral de vontade do Estado (Direito Administrativo Brasileiro, Ed. Forense, v. I, p. 255, 1983), "é a supressão de um ato administrativo baseada em critérios de interesse público da mesma natureza daqueles na base dos quais tal ato foi editado" (Tratado..., cit., p. 169).

Hely Lopes Meirelles (Direito Administrativo Brasileiro, cit., pp. 34850) relaciona como causas extintivas da concessão, o término do prazo, a encampação ou resgate, a rescisão contratual e a anulação, nos mesmos termos expostos, sem falar em revogação. Celso Antonio Bandeira de Mello (Curso de Direito Administrativo, cit., pp. 339-40) arrola as hipóteses de expiração do prazo fixado no ato da concessão, rescisão judicial (pelo concessionário, ou pelo concedente, "se optar pelo recurso às vias judiciais"), rescisão consensual, rescisão por ato unilateral (abrangendo a encampação ou resgate, e a caducidade ou decadência), morte e falência. Também assim pensa Maria Sylvia Zanella Di Pietro (Direito Administrativo, cit., pp. 219-20), reafirmando a característica unilateral das hipóteses de encampação e caducidade.

Permissão d Serviço Público

10. A outra modalidade de delegação de serviços públicos a particulares, constante do art. 175 da Constituição Federal e arrolada pela Lei $\mathrm{n}$. 8.987/95, é a permissão de serviço público.

Tratávamos do assunto, já na vigência da Constituição de 1988 (nosso Do negócio jurídico administrativo, Ed. Rev. Trib., p. 134, 1992), lembrando que no caso em que o serviço público é transferido pela chamada "permissão de serviço público", deve-se aferir se o é a título precário e sem prazo certo, em caráter 
interino ou emergencial, caso em que se terá ato administrativo stricto sensu, unilateral, embora a outorga dependa de provocação e aceitação do permissionário.

É como sempre entendeu a doutrina tradicional, diferenciando a permissão, principalmente do caráter contratual da concessão. Mas a partir da nova Carta, esse entendimento não é absoluto.

"Se tal permissão, no entanto, se der de forma condicionada, exigindo-se investimentos e outros requisitos, $e$, principalmente, se for convencionado prazo certo para a extinção da permissão, esta será a permissão qualificada, a cuja estabilidade se submeterá a Administração, só podendo extinguí-la antecipadamente nos casos mencionados para os contratos de concessão: na verdade, o termo expresso e determinado elimina a precariedade $e$ atribui à permissão qualificada natureza claramente contratual, como aliás é atualmente tratada (art. 175, I, da Constituição Federal)" (idem, ibidem)

Veja-se, a propósito, que Celso Antonio Bandeira de Mello (Curso de Direito Administrativo, cit., pp. 346-8), indica como características da permissão, a unilateralidade, a precariedade, o intuitu personae, e a revogabilidade, porque " $o$ Estado vale-se da permissão justamente quando não deseja constituir o particular em direitos contra ele, mas apenas em face de terceiros", como aliás é da jurisprudência do STF ( $R D A$ 54:44 e 96:121), citada pelo autor. Mas entende que a permissão tem sido desnaturada pela inclusão de condições e elementos que lhe retiram a indispensável precariedade.

Significativamente, na nota n. 24 (p. 346), alerta que, embora o parágrafo único, inciso I, do art. 175 da CF, “que trata conjuntamente de concessões e permissões, fale em "contrato" evidentemente o fez com imprecisão técnica de redação, pois a expressão obviamente só pode estar reportada às concessões, embora, do modo como está posta a linguagem normativa, abarcasse a ambas."

Também Diogo de Figueiredo Moreira Neto (Curso de Direito Administrativo, Ed. Forense, pp. 384-6, 1989) conceitua a permissão de serviço público como ato administrativo discricionário e precário, que se extingue pela revogação dependente da simples vontade da Administração, "sem qualquer indenização devida ao permissionário" Não é diferente a posição de Celso Ribeiro Bastos (Curso de Direito Administrativo, Ed. Saraiva, pp. 181/182, 1994), para quem a permissão de serviço público, ao contrário da concessão, que tem prazo 
certo, tem como característica principalmente "não prever um prazo certo para sua duração" e, por isso, "ser ela revogável unilateralmente e a todo tempo e sem qualquer indenização ao permissionário" fiel à sua configuração como "ato unilateral e precário" que é. Mas ressalva que hoje em dia encontram-se permissões também com prazo certo, mesmo não se referindo a contrato para sua outorga: este é formalização característica da concessão de serviço público.

Maria Sylvia Zanella Di Pietro (Direito Administrativo, cit., pp. 2201) também conceitua a permissão de serviço público como ato unilateral, discricionário, precário, intuitu personae, revogável a qualquer momento pela Administração, por motivo de interesse público, e, ao mencionar a possibilidade de permissões com prazo, admitidas pela doutrina, considera que isto vem a desnaturar o instituto, pois sob a forma de permissão "condicionada" ou "qualificada" o que se nota é que a Administração celebra verdadeiros "contratos de concessão", sob a forma de permissão, pois "a fixação de prazo aproxima de tal forma a permissão da concessão que quase desaparecem as diferenças entre os dois institutos." É claro que, sendo relação contratual, bilateral, não pode ser revogada unilateralmente; entretanto, como qualquer contrato de concessão, pode ser rescindida mas as conseqüências serão diferentes, pois na rescisão pode-se falar de indenização ou ressarcimento. Os doutrinadores que a autora menciona são José Cretella Jr. (Teoria e prática do Direito Administrativo, Ed. Forense, pp. 81 e ss., 1979) e Hely Lopes Meirelles (Direito Administrativo Brasileiro, cit., pp. 171-2).

$\mathrm{O}$ primeiro enquadra a permissão entre os atos unilaterais, necessariamente revogável, ao contrário da concessão, bilateral (p. 81). Mas admite o termo certo e a onerosidade (pp. 89-90) na permissão, o que diminui a gradação de sua precariedade (p. 95), configurando a permissão qualificada que, embora ato unilateral ainda (o autor escrevia antes da CF vigente) submete a Administração ao prazo que ela estabeleceu (pp. 95-6). O segundo também conceitua a permissão como ato administrativo discricionário e precário, mas admite (p. 171) a "permissão condicionada, ou seja, aquela em que o próprio Poder Público autolimita-se na faculdade discricionária de revogá-la a qualquer tempo fixando em norma legal o prazo de sua vigência elou assegurando outras vantagens ao permissionário, como incentivo à execução do serviço. Assim reduzem-se a discricionariedade e a precariedade da permissão às condições legais de sua outorga." A Administração pode revogar ou alterar a permissão, mas, como nos contratos de concessão, 
respeitando o equilíbrio contratual e indenizando o permissionário, pois este (p. 172) "tem direito subjetivo ao cumprimento integral da permissão originária"

\section{Casos de Revogação}

11. Resumindo: A concessão outorgada por lei ou outra norma jurídica, pode ser revogada pela mesma via. Mas depois da CF de 1988, não é mais possível a concessão de serviço público que não se configure por relação contratual, podendo existir concessões de outras espécies (de uso de bem público, de lavra de minerais, p. ex.) que ainda podem tomar essa forma.

A concessão concretizada por contrato administrativo não pode ser "revogada" porque é ato bilateral. Corretamente, ela poderá ser desfeita por rescisão, em suas quatro espécies: amigável, judicial, por infração contratual ou por razões de interesse público, às quais, na concessão, correspondem a rescisão amigável, judicial, caducidade e encampação, além, obviamente, da anulação, falecimento ou incapacidade do concessionário, falência ou extinção da empresa concessionária e término do prazo contratual.

A permissão outorgada a título precário, sem prazo certo, por ato unilateral, pode ser revogada a qualquer tempo, sem indenização ou ressarcimento. Já a permissão qualificada, mesmo unilateral (depois da Lei n. 8.987/95, a de serviço público o será contratualmente), com prazo e condições contratuais, deve ter seu termo respeitado, podendo ser rescindida por infração contratual (caducidade) ou por interesse público (encampação), amigável ou judicialmente, pois a fixação do prazo elimina a precariedade.

Jurisprudência sobre Concessões e Permissões

12. Vejamos, a propósito, o trato jurisprudencial que tem sido dado às características de estabilidade ou precariedade dos dois institutos, e, conseqüentemente, das hipóteses de seu desfazimento.

a) "A faculdade de rescisão está implícita em todas as concessões, tendo em vista o interesse público, assegurada ao concessionário a indenização por danos e prejuizos sofridos, se improcedente a causa alegada para a rescisão" (STF, em RDA 95:121). "Concessão é um acordo de vontades com obrigações recíprocas; a permissão ou autorização é ato administrativo de caráter precário, revogável 
segundo a conveniência e oportunidade pública" (TJSP. em RDA 87:197). "Na vigência da concessão, não pode o poder concedente outorgar a terceiro a exploração parcial do serviço" (TJSP, em RDA 80:165). "Não se confunde a concessão com a simples autorização ou permissão" (TASP, em RDA 46:136). " $A$ teoria da concessão, como contrato de direito público, é a mais lógica e de acordo com a realidade. A concessão é um contrato típico de direito público, ainda que bilateral seja, e representa uma delegação do Estado ao particular para o desempenho de um serviço público ou de interesse público. Caracteriza-se a subordinação do concessionário ao Estado e o seu controle através do poder de polícia, para salvaguarda do interesse público" (TFR, em RT 40:327). "Na concessão de serviço público, como ato complexo, meio regulamentar, meio contratual, o poder concedente pode modificar, mediante lei, o funcionamento do serviço, alterar o regime dos bens públicos nela envolvidos e até impor novos ônus ao concessionário, desde que lhe assegure o equilíbrio financeiro necessário à remuneração e amortização do capital efetivamente investido" (STF, em RF 226:51) (Obs.: Este aresto, que havia perdido aplicabilidade com a Constituição de 1988, que não mais exige autorização legislativa para as concessões, deve ter nova aplicabilidade às concessões não-elencadas pela Medida Provisória n. 890, de 15 de fevereiro de 1995, ou à lei que lhe suceder, se o for nos mesmos termos) "Contrato administrativo-Concessão de serviço público-Alterações nas condições objetivas do serviço-Possibilidade-Necessidade de observância do equilibrio financeiro da empresa concessionária. No contrato de concessão de serviço público, ao Estado é lícito alterar as condições objetivas do serviço, desde que o faça sem romper com o equlíbrio financeiro da empresa concessionária" (TISP, em RT 608:96). "Contrato administrativo-Concessão de serviço público-Modificação unilateral pela concessionária da cláusula atinente à remuneração do serviço-Quebra do equilíbrio econômico-financeiro que autoriza a medida-Alteração de preço. Sendo a concessão de serviço público modalidade de contrato administrativo, o qual não se confunde com o de adesão, tipicamente privado, garantida é ao concessionário, através da cláusula do equilíbrio econômico-financeiro do contrato, a remuneração condizente com o serviço prestado, o que, de outra forma, resultaria na sua máqualidade, que não é intenção da Administração Pública, garantida lhe sendo, também, a alteração do preço sempre que houver um aumento no seu custo" (TJMG, Ap. Civ. 79.185-2, em RT 658:159). "Contrato administrativo-ConcessãoUso de bem público-Atividade hoteleira-Possibilidade de alteração e de rescisão 
unilateral pela Administração-Predominância do interesse público sobre o particular-Segurança cassada" (TJSP, em RJTJESP 107:73). "Contrato administrativo-Alteração de cláusula financeira-Inadmissibilidade-Modificação que implica em rompimento com o critério remuneratório no contrato convencionadoSentença confirmada. A concessão de serviço público é modalidade de contrato administrativo e, portanto, subordina-se ao regime dessa espécie de avença. Ao contrário do que ocorre com os contratos de direito privado, nos contratos administrativos pode ocorrer a alteração unilateral das cláusulas contratuais, já que o concessionário se submete à ingerência do Poder Público não-só em relação ao objeto do ajuste como na própria execução do contrato, restando-lhe tãosomente o direito à retribuição pela prestação do serviço, conforme os critérios fixados na convenção" (TJSP, em RJTJESP 104:98).

b) "Adquirido o direito à exploração do serviço de transporte coletivo, não pode a Administração revogá-la unilateralmente, com prejuizo da empresa permissionária" (STF em RDA 97:185, permissão com prazo certo). "A concessão é um acordo de vontades, com obrigações recíprocas; a permissão ou autorização é ato administrativo de caráter precário, revogável segundo a conveniência e oportunidade pública" (TJSP, em RDA 87:197). “A permissão concedida por prazo certo, para exploração de linhas de ônibus, somente pode ser revogada por motivo justo, previsto em lei ou regulamento" (TJSP, em RDA 110:253). "A permissão, em princípio, é concedida sempre em caráter precário, não gerando quaisquer privilégios, nem manietando a Administração Pública, salvo convenção expressa em contrário. E, como ato a título precário, poderá, a qualquer tempo, ser revogado" (TJSP. em RT 467:63). "Não pode o prefeito cassar permissão administrativa para exploração de serviços funerários auxiliares, sem inquérito regular e com cerceamento de defesa das interessadas" (STF, em RDP 26:147). "Pode ser revogada permissão, a título precário, para a exploração de linha de ônibus municipal" (STF, em RDP 26:148). "Bem público-Permissão de uso-Cláusula de livre revogação pelo permitente-Anulação do dispositivo pretendida com fundamento no art. 115 do CC-Inadmissibilidade-Ato negocial, unilateral, discricionário e precário onde se permitem as cláusulas exorbitantes ao Direito Comum-Prevalência das disposições de Direito Público. Os contratos públicos da Administração têm características especialíssimas, exorbitantes das normas de Direito Comum, por estarem em jogo fins de interesse público, permitindo-se neles, portanto, a adoção de cláusulas ditas exorbitantes, decorrentes 
de normas especiais. Legal, portanto, a cláusula de rescisão unilateral em proveito da Administração" (TJSP, em RT 651:60). "Permissão de uso-RevogaçãoReintegração de posse-Meio idôneo-Impropriedade da ação de despejo-Inexistência de relação locatícia. A permissão de uso é ato unilateral pelo qual a Administração permite a utilização precária de bem público, no interesse exclusivo e predominante do permissionário, e pode ser revogado a qualquer tempo, dando ensejo a ação de reintegração de posse, uma vez que não se configura como contrato de locação com caráter de Direito Privado, visto ser o Poder Público parte sujeita a direitos e obrigações distintos dos concernentes aos particulares." (2 ${ }^{\circ}$ TAC-SP, em RT 616:140). "Permissão-Táxi-Cassação de inscrição e do alvará de estacionamentoAlegação de envolvimento do taxista em greve-Necessidade de prévia instauração de procedimento administrativo-Lei Municipal n. 7.329, de 1969-Arbitrariedade e ofensa a direito líquido e certo configuradas-Segurança concedida... A ordem rogada foi concedida sob o fundamento de tratar-se de permissão condicionada, razão porque sua cassação deveria obedecer a prévio procedimento administrativo, exigido pela Lei n. 7.329, de 1969, inocorrido no caso em exame"... "negam provimento aos recursos" (TJSP, em RJTJESP 116:195). "Contrato-Permissão de uso-Prorrogação-Inadmissibilidade-Precariedade do contrato, sujeito ao interesse público-Inexistência, ademais, de valor em prorrogação-Carência decretadaRecurso não-provido" (TJSP, em RJTJESP 134:55). "Simples permissionário de linha de transporte de passageiros, que a explora em caráter precário, não tem direito líquido e certo de opor-se à abertura de concorrência para sua adjudicação" (TJRS, em RF 235:208).

A Nova Lei Federal: Comentários Objetivos

13. Passemos agora, mais objetivamente, a verificar como a Lei $n$. 8.987, de 13 de fevereiro de 1995, disciplinou os vários aspectos concernentes a concessões e permissões de serviço público.

a. no art. $1^{\circ}$, estabelece-se que a lei aplica-se às concessões e permissões, nos termos do art. 175 da Constituição Federal, "das normas legais pertinentes", bem como das "cláusulas dos indispensáveis contratos" Por isso, seria até dispensável o parágrafo único do art. 40 , que diz ser a lei também aplicável às permissões. 
Isto quer dizer que as permissões de serviço público, doravante, só podem ser outorgadas através de contrato que, analisando-se sistematicamente o direito positivo, será contrato administrativo.

A idéia de outorga de permissão por contrato já havia sido objeto de críticas na doutrina, com relação à ambigüidade da redação do art. 175, parágrafo único, inciso I, da CF, entendendo-se (Celso Antonio Bandeira de Mello, Curso de Direito Administrativo, cit., p. 346, nota 24) que a expressão "caráter especial de seu contrato" que lá consta só pode estar reportada às concessões, pois a permissão de serviço público seria ato unilateral, discricionário, precário e necessariamente revogável, como sempre foi (como verificamos anteriormente), no direito positivo, doutrina e jurisprudência, com a exceção apontada da permissão qualificada ou condicionada, que tem conotação contratual.

José Cretella Jr. (Comentários à Constituição de 1988, Ed. Forense Universitária, p. 4.108, 1993) é mais contundente: "Tratando, em conjunto, dos dois institutos, da concessão e da permissão, o legislador constituinte, desconhecendo princípios básicos de Direito Administrativo, comete erros palmares, atribuindo à permissão atributos que somente caracterizam a concessão. Da futura lei ordinária deverão constar inúmeros traços do regime das concessionárias e permissionárias, referentes ao Estado, ao usário e ao empresário, tais como, por exemplo: a) o caráter especial de seu contrato, b) a prorrogação do prazo, c) a caducidade, d) a fiscalização, e) a rescisão, f) os direitos do usuário, g) a política tarifária, h) a obrigatoriedade da manutenção do serviço adequado. Ora, as conotações (a) e (e) aplicam-se à concessão, sendo estranhas à permissão. A concessão, como contrato, rescinde-se; a permissão, como ato unilateral, revoga-se. $A$ expressão caráter especial de seu contrato aplica-se, tão-só, à concessão."

Enquanto conjeturávamos se tais opiniões, de dois dos mais importantes administrativistas do país, teriam o condão de induzir a Jurisprudência ao posicionamento que ela sempre adotou, vem a Lei n. 8.987/95 e envereda pelo caminho oposto.

Então, se a concessão e a permissão se farão, indispensavelmente por contrato administrativo e se, além de tudo, se regem pelas disposições pertinentes a essa classe de contratos, temos que:

I) Lei n. 8.666, de 21 de junho de 1993:

"art. 55 - São cláusulas necessárias em todo contrato as que estabeleçam: 
IV- os prazos de início, de etapas de execução, de conclusão, de entrega, de observação e de recebimento definitivo, quando for o caso;" (grifos nossos)

Obviamente, adaptado às concessões e permissões, prazos de início e fim e outros prazos eventualmente intermediários.

II) Na própria Lei n. 9.987, de 13 de fevereiro de 1995:

"art. 23 - São cláusulas essenciais do contrato de concessão, as relativas:

I- ao objeto, à área e ao prazo da concessão;" (grifos nossos).

Ora, se $o$ art. $1^{\circ}$ e o parágrafo único do art. 40 dizem que também na permissão o contrato é indispensável e que a lei se aplica "também" às permissões, o "contrato de permissão" deverá ter, necessariamente, uma cláusula de prazo. Vejamse, também, os arts. $5^{\circ}$ e 18 , inciso I, sobre a obrigatoriedade da definição do prazo.

Isto, como se viu, retira o caráter precário da permissão, transformando-a em permissão "qualificada" ou "condicionada", e desnudando a incompatibilidade e impropriedade do art. 40, caput, o qual diz que o contrato de permissão, "que observará os termos desta lei, das demais normas pertinentes e do edital de licitação" deverá prever a precariedade e a revogabilidade unilateral pelo poder concedente (no caso, permitente), uma e outra impossiveis em se tratando de permissão condicionada, com prazo fixado (que é obrigatório), como vimos anteriormente. Na verdade, o art. 175, parágrafo único, da $\mathrm{CF}$. alude também à "rescisão" da permissão, que José Cretella Jr. ("Comentários à Constituição de 1988, citado, p. 4.127) prefere "denominar de revogação, já que a permissão é ato, e não contrato."

Aliás, esse mesmo art. 40, como que querendo diferenciar o contrato de permissão do contrato de concessão, diz que o primeiro é contrato de adesão. Ora, como é curial e firmado pela doutrina, todos os contratos administrativos, dada a posição de supremacia da Administração na relação jurídica, o são. E se esses contratos não fossem administrativos, nem mesmo teria legitimidade a União para disciplinar privativamente as normas gerais a respeito para os vários níveis da Administração, como está no art. 22, inciso XXVII, da Constituição Federal

Será que se pensou em uma cláusula que dissesse que a permissão não tem prazo de término, por isso seria precária e revogável unilateralmente? Ou então que, tendo prazo, seria precária e revogável sem indenização? Não desejamos acreditar em tais desatinos. 
É verdade que a precariedade tem gradações, na prática, e nesse sentido, mesmo os contratos de concessão de serviço público (ou qualquer outro tipo de contrato administrativo) seriam, por assim dizer, sem precisão técnica, "precários", pois podem ser rescindidos unilateralmente pelas chamadas "razões de interesse público". Mas, nesse caso, não são "revogáveis unilateralmente", o que não acarreta indenização ou ressarcimento, mas "rescindiveis" ou "encampáveis" (no caso da concessão de serviço público), o que, como vimos, acarreta.

b. o art. $2^{\circ}$, inciso I, considera poder concedente só as pessoas políticas (União, Estados-membros, Distrito Federal, Municípios), quando é indiscutível que o Poder Público pode transferir, por lei, até mesmo a titularidade de certos serviços públicos a entidades por ele criadas, principalmente as autarquias. É claro que se pode interpretar assim, mas seria melhor a explicitude.

c. art. $2^{\circ}$, inciso III: Aqui, o erro é gramatical, de vernáculo, pois fala em "construção" de obra. Ninguém "constrói" uma obra, mas realiza-se uma obra, mediante: 1. construção total ou parcial; 2. conservação; 3. reforma; 4. ampliação; 5. melhoramento, de qualquer edifício publico, prédio ou equipamento, como estradas, pontes, viadutos, etc. E fala em "exploração da obra", repetindo o erro: explora-se $o$ serviço público, para cujo desempenho realizou-se uma obra qualquer, pois explorar a própria obra significaria, por exemplo, expô-la à visitação pública, cobrando ingressos para isso, enquanto a obra estivesse sendo realizada, antes de pronta para o uso público.

d. art. $2^{\circ}$, inciso IV: Ao conceituar a permissão de serviço público, é contraditório com outros dispositivos da lei, pois não fala em prazo determinado, como nos incisos II e III (concessões) e considera precária a permissão. Este dispositivo, apesar de contraditório, é o que está correto, os outros é que são inadequados.

e. art. $9^{\circ}, \S 2^{\circ}$ : Diz que os contratos "poderão" prever mecanismos de revisão de tarifas, para manter o equilíbrio contratual, em vez de "deverão" (art. 175, parágrafo único, da CF; arts. 55, inciso III; 57, $\S \S 1^{\circ}$ e $2^{\circ}$; e 65 , inciso II, "b" e "d", a Lei n. 8.666/93), que, inclusive, está em contradição com o $\S 4^{\circ}$ do mesmo art. $9^{\circ}$ da Lei n. 8.987/95.

f. o art. 10 se presta a interpretações falaciosas. Quando ocorre um caso de aplicação da "teoria da imprevisão", fundamentado na regra rebus sic stantibus (ver nosso Contrato Administrativo, citado, p. 22 e 26), as condições do contrato são formalmente mantidas, mas, por fato imprevisto e imprevisivel, alheio à 
vontade das partes, o equilíbrio econômico-financeiro original, na prática, se rompe, justificando revisão ou até mesmo o desfazimento da relação obrigacional.

g. art. $15, \S 3^{\circ}$ : Verifica-se, por exclusão, que pode concorrer empresa estrangeira. Mas seria melhor, se essa é a intenção, que o dissesse expressamente, disciplinando o que fosse necessário mais detalhadamente.

h. art. 16: Estabelece, como princípio, a "não-exclusividade" da concessão ou permissão, contrariando toda a Jurisprudência firmada até esta data. Melhor seria o contrário, exclusividade como princípio, em área determinada, com exceções.

i. art. 18, incisos XIV e XVI: Pela redação dos incisos, poder-se-ia inferir que as cláusulas essenciais do art. 23 só seriam obrigatórias para o contrato de concessão, e para o de permissão, como vimos, não é verdade. Até parece que pessoas diferentes redigiram dispositivos diferentes e depois os juntaram, sem compará-los e compatibilizá-los !!!

j. art. 19, § $1^{\circ}$ : Obriga a formalizar o consórcio só para a assinatura do contrato. Como se resolveria, então, o caso de um consórcio vencedor, nãoformalizado, em que uma das empresas, entre a adjudicação e a contratação, desistisse de sua participação? Não seria melhor que o consórcio já estivesse constituído para participar da licitação? Ou, ao menos, exigir-se já na habilitação, um compromisso de consórcio subscrito pelos consorciados, como é determinado pelo art. 33, inciso I, da Lei n. 8.666/93?

k. no art. 22, assegura-se a obtenção de certidões da licitação ou da concessão a qualquer pessoa. Na Constituição Federal, art. $5^{\circ}$, inciso XXXIV, "b", exige-se a demonstração do legítimo interesse, "para defesa de direitos $e$ esclarecimento de situação de interesse pessoal" Para se evitar entraves burocráticos protelatórios, capazes de prejudicar os procedimentos e a atividade da Administração, deve o dispositivo ser interpretado no sentido da Constituição e também que "certidão" abranja cópias xerográficas ou similares autenticadas pelo funcionário responsável.

1. autores há que não admitem ou que ao menos contestam a possibilidade de subcontratação em concessð̃es de serviço público (v.g., José Cretella Jr., Celso Antonio Bandeira de Mello, e Maria Sylvia Zanella Di Pietro), pois sendo tal contratação intuitu personae, estar-se-ia burlando o princípio da licitação, obrigatória pelo art. 175 da CF. Mas nos termos do art. 26 da Lei $n$. $8.987 / 95$, a "subconcessão" configura nova concessão, embora parcial, pois pela 
licitação e pela própria característica intuitu personae, exonera-se o contratado original da responsabilidade pela subcontratação. E a permissão, não pode ser "subpermitida"?

m. art. 29, IX: Esqueceram-se (provavelmente...) de colocar declaração de utilidade ou necessidade públicas para fins de desapropriação, o que, aliás, é mencionado no art. 31, inciso VI. A promoção expropriatória, com declaração de utilidade ou necessidade públicas feita privativamente pelo Chefe do Executivo, é exemplo sempre citado de cláusula exorbitante dos contratos administrativos.

n. art. 35: Não se apontam os casos de extinção das permissões, embora no art. 40 se fale em revogação e que a lei se aplica às permissões.

o. art. 37: Está subordinando a encampação a "lei autorizativa específica" Esta autolimitação do Poder Público é desnecessária e mesmo de legitimidade duvidosa, pelo princípio da indisponibilidade do interesse público, pois nada a obriga e o direito à encampação é decorrente da própria titularidade do serviço público, não precisando nem constar das cláusulas contratuais expressamente. Além disto, trata-se de "poder-dever" do concedente, podendo até acarretar a responsabilidade da autoridade, se não exercitado, como se viu nas referências jurisprudenciais e doutrinárias. E no caso da permissão qualificada? Paga-se, também, a indenização, apesar da "revogabilidade" e da "precariedade"?

p. art. $38, \S 4^{\circ}$ : Porque declarar por decreto a caducidade? Isto resumiria a declaração aos Chefes de Poder Executivo e ao plenário dos Poderes Legislativos, por ser o decreto ato administrativo privativo; isto vai obrigar a uma ginástica interpretativa, ou a delegação de competências em cada esfera da Administração.

q. art. 39: Não se prevê a rescisão judicial por iniciativa do concedente (embora seja óbvio que não se pode negar-lhe esse direito processual, quer pela sua natureza de pessoa jurídica, quer pela garantia geral do art. $5^{\circ}$, inciso XXXV da CF, quando mais não fora). Pode interessar a este essa via, por exemplo, para exonerá-lo de indenização ou ressarcimento.

r. art. 40: Já foi bastante comentada sua impropriedade.

s. art. $42, \S 2^{\circ}$ : Fala em concessões em "caráter precário" que não existem, pela sua própria natureza; por prazo indeterminado, que seriam ilegais por não conter a cláusula essencial relativa ao prazo; e que tiverem prazo já vencido, em que não mais existe uma relação jurídica que possa ser prorrogada. Além disso, a Lei 
n. 8.666/93, que trata de licitações e contratos em geral para a Administração, proíbe os efeitos pretéritos de aditamentos ou prorrogaçð̃es. Como, então, se diz que "permanecerão válidas" concessões que não são mais válidas?

t. art. 45: A condição imposta para viabilizar a indenização é incabível. Na Justiça, as concessionárias ganharão a indenização, independentemente do Poder Público abrir nova licitação.

u. medida Provisória n. 890, de 13 de fevereiro de 1995: $O$ art. $1^{\circ}$ arrola os serviços passíveis de concessão ou permissão, mas de modo exaustivo e não-exemplificativo, subordinando a terceirização de outros serviços a lei autorizativa. É verdade que está prevista a maioria das hipóteses possíveis, mas não todas: serviços nas áreas de esportes, de turismo, ou da cultura, por exemplo, dependeriam de nova lei.

v. art. $3^{\circ}$ : É incrivel o "cheque em branco" dado à Administração, burlando o princípio constitucional da licitação e mesmo da legalidade e vinculação dos contratos administrativos. Nos artigos $4^{\circ}$ e 16 , também saltam aos olhos os privilégios, em especial às estatais prestadoras de serviços públicos.

x. art. 12, II: A União poderia ainda fundir, cindir ou transferir concessð̃es mesmo de empresas privadas?

z. finalmente, uma dúvida de caráter geral, sobre a Lei n. 8.987/95 e sobre a Medida Provisória: o que pode ser considerado como "norma geral" e o que não o seria, pois, ao contrário da Lei n. 8.666/93, não se diz que "tudo" dessas normas jurídicas é norma geral, legitimando sua obrigatoriedade para as demais pessoas políticas da Federação?

Confronto entre a Lei Federal e a Estadual N. 7.835/92

14. Vejamos, finalmente, no que as disposições da Lei federal $n$. 8.987/85 implicam em alteraçð̃es ou adaptaçð̃es para a Lei estadual n. 7.835, de 8 de maio de 1992.

a. art. $2^{\circ}$, inciso II: Está mais certo que a lei federal, mas ainda assim fala em "construção de obra", como a outra.

inciso IV Deve ser modificado, pois agora a relação será contratual. Embora, como vimos, esteja a conceituação absolutamente correta em relação à doutrina e jurisprudência anteriores à lei federal, esta dispõe de outra forma. 
b. o art. $4^{\circ}$ só pode ser mantido até a palavra "contratos" A lei federal não prevê a dispensa de licitação, embora seja admitida pela Lei n. 8.666/93: portanto, eliminam-se também os incisos I, II e III, bem como os $\S \S 1^{\circ}$ e $2^{\circ}$ do artigo.

c. art. $8^{\circ}$ : Inciso II confunde-se com a concessão de obra pública, que já é tratada mais adiante. Mas pode ficar.

Incisos VII e VIII, que tratam de recursos financeiros e provisões para depreciação: embora não constem da lei federal, podem, aliás devem ser mantidos.

Inciso XVI, que trata das penalidades a serem aplicadas eventualmente aos usuários dos serviços: É duvidosa sua legitimidade, sem lei que as autorize (art. $5^{\circ}, \mathrm{II}, \mathrm{da} \mathrm{CF}=$ Ninguém será obrigado...etc.).

Inciso XIX, poderes para desapropriar: não está no artigo correspondente da lei federal, mas está em outro da mesma. Pode ficar, portanto.

Inciso XX A lei federal não fala em prorrogação, embora a Lei $n$. $8.666 / 93$ e a própria Constituição Federal, no art. 175 , $\S$ único, inciso I, a mencione. A Medida Provisória também a prevê, para concessões de energia elétrica. Como a União legisla sobre normas gerais e só a lei de concessões não a menciona, pode-se interpretar no sentido da admissibilidade de prorrogação, prevista no Edital e devidamente justificada caso a caso.

d. art. $9^{\circ}: \mathrm{O} \S 1^{\circ}$ pode ser mantido, desde que seja feita a mencionada alteração no art. $4^{\circ}$ para não permitir dispensa ou inexigibilidade de licitação.

e. art. 10, §único: o mesmo comentário feito ao inciso XX do art. $8^{\circ}$, referente à possibilidade de prorrogação.

f. art. 15: Embora não constem no artigo respectivo da lei federal, devem ser mantidos os incisos IX, X e XI, além dos demais.

g. art. 21: Fala em procedimento "sumário", com garantia de defesa. Isto é peculiaridade local, mas o $\S 3^{\circ}$ do art. 38 da lei federal exige "comunicação prévia" do descumprimento contratual, antes de instaurado o procedimento.

h. art. 24: Estaria certo, pela doutrina e jurisprudência, mas o artigo 37 da lei federal subordina, desnecessariamente, como vimos, a encampação a "lei autorizativa específica"

i. art. 25: Também não prevê, como a lei federal, rescisão judicial pelo concedente, mas este, independentmente disso, tem esse direito. 
j. art. 27: Intervenção é praticamente igual ao da lei federal, só que esta exige decreto para a intervenção. Neste caso específico, achamos melhor a lei federal.

$\S 2^{\circ} \quad$ A lei federal não fixa esse prazo de 180 dias para a vigência da intervenção. Pode ficar, como autolimitação, ou adaptar-se.

k. art. 28: A lei federal (art. 33), o prazo para instauração do procedimento é de 30 dias, em vez de 15 . Pode ficar ou adaptar-se.

1. $\S 2^{\circ}$ O prazo para conclusão do procedimento administrativo, na lei federal (art. 33, $\S 2^{\circ}$ ), é de 180 dias, e não de 90 . Também pode ficar como autolimitação, ou adaptar-se.

m. art. 32: No inciso II fala-se em contribuição de melhoria, etc, que não estão expressamente citados na lei federal. Mas nesta, o art. 11 fala em receitas alternativas, o que pode compatibilizar-se com as medidas da lei estadual.

n. art. 33, que fala em formalização da permissão por "ato apropriado" A lei federal exige expressamente o contrato. Além disso, a permissão federal não se aplica só a situações de urgência ou emergência, como a estadual (arts. $2^{\circ}$ inciso IV e 34).

o. art. 34: Parágrafo único estaria certo, mas como a lei federal exige o contrato, não poderá haver revogação unilateral, sem indenização, apesar do que diz o art. $40, \S$ único, da lei federal, já comentado anteriormente.

Conclusão

15. Em conclusão, no confronto da legislação federal com a Lei estadual n. 7.835, de 8 de maio de 1992, verifica-se que embora esta última repita certas imperfeições da lei federal, foi melhor elaborada e, com poucas exceções, compõe-se de dispositivos exeqüíveis, ao contrário da lei federal, que envereda por várias aberrações jurídicas, a merecer reforma. Mas, por isso, há certos dispositivos da lei estadual que, em obediência ao art. $1^{\circ}$, $\S$ único, da Lei federal n. 8.987/95, devem ser alterados. Isto não impede, entretanto, que se elabore novo projeto, mais conciso e "balanceado" "compatibilizado" pois a disciplina suplementar dessa matéria inclui-se na iniciativa legislativa dos demais entes federativos, cabendo à União, como vimos, a iniciativa privativa para normas gerais. 